\title{
Journal of American Studies
}

http://journals.cambridge.org/AMS

Additional services for Journal of American

Studies:

American

Email alerts: $\underline{\text { Click here }}$

Subscriptions: Click here

Commercial reprints: $\underline{\text { Click here }}$

Terms of use : $\underline{\text { Click here }}$

\section{Response to lan Tyrrell, "America's National Parks: The Transnational Creation of National Space in the Progressive Era"}

\section{ASTRID SWENSON}

Journal of American Studies / Volume 46 / Issue 01 / February 2012, pp 37 - 43

DOI: 10.1017/S0021875811001459, Published online: 09 March 2012

Link to this article: http://journals.cambridge.org/abstract S0021875811001459

How to cite this article:

ASTRID SWENSON (2012). Response to lan Tyrrell, "America's National Parks: The Transnational Creation of National Space in the Progressive Era". Journal of American Studies, 46, pp 37-43 doi:10.1017/S0021875811001459

Request Permissions : $\underline{\text { Click here }}$ 


\section{Response to Ian Tyrrell, “America's National Parks: The Transnational Creation of National Space in the Progressive Era"}

\section{ASTRID SWENSON}

How national are the origins of the national park? Ian Tyrrell challenges the widespread belief, propagated by American academics, public historians and foreign scholars alike, that the national park was a quintessentially American creation stemming from the nation's innate and somewhat unique love of its western wilderness. By linking the genesis of the national parks in America to developments and debates across the British Empire, Argentina and a range of European countries including Sweden, Switzerland, Germany, France and Belgium, Ian Tyrrell not only shows that the origins of the national park in America were transnational rather than national, but also demonstrates that the motives behind early American nature conservation were much more complex than the familiar tale of cultural nationalism would have us believe.

The vast majority of research on conservation is still adopting a national angle; however, Tyrrell's reflection contributes to a growing body of scholarship that rethinks this history in a comparative and transnational manner. ${ }^{\mathrm{I}}$ Scholars from across the world started examining the global spread of the national park concept during a conference on Civilizing Nature: National Parks in Transnational Historical Perspective held at the German Historic Institute in Washington in 2008. While here the place of Yellowstone as a headspring for global developments was largely maintained, ${ }^{2}$ Melanie Hall has analysed the transatlantic ties that informed not just the protection of Niagara Falls but also

Department of Politics and History, Brunel University. Email: astrid.swenson@brunel.ac.uk.

${ }^{1}$ On the global turn in environmental history see, for example, Christoph Mauch, Nathan Stoltzfus and Doug Weiner, eds., Shades of Green: Environmental Activism around the Globe (Oxford: Rowman \& Littlefield, 2006).

${ }^{2}$ Tagungsbericht "Civilizing Nature: National Parks in Transnational Historical Perspective," I 2 June 2008-I 4 June 2008, Washington, in H-Soz-u-Kult, 08 Aug. 2008, available at http:// hsozkult.geschichte.hu-berlin.de/tagungsberichte/id=2220; Bernhard Gißibl, Sabine Höhler and Patrick Kupper, eds., Civilizing Nature: National Parks in Global Historical Perspective (Oxford and New York: Berghahn Books, forthcoming 2012). 
many other preservation campaigns on both sides of the anglophone Atlantic. ${ }^{3}$ The national origins of nature conservation in Europe (where national foundation myths are as strong as in America despite the occasional invocation of Yellowstone as a model and icon) are also being challenged. Transnational origins appear equally important in the creation of the Swiss national park, ${ }^{4}$ as they do in the emergence of the interlinked nature and culture preservation movements in Germany, France and Britain. ${ }^{5}$ Growing attention is, moreover, being paid to the exchange of ideas within and across European empires. We are also starting to better understand the drive to regulate conservation internationally, first through civil-society initiatives and diplomatic conventions and later through the League of Nations and the UN. ${ }^{6}$

The intensity of transnational exchange explains why so many similarities can be observed across national borders. Tyrrell's case study of the American Scenic and Historic Preservation Society shows that the national park movement was not purely driven by a "wilderness ethic," but also stemmed from "a social and cultural aesthetic as well." Inspired by the writings of John Ruskin and William Morris, who culturalized nature and naturalized culture, the American society, like many of the European preservation bodies it was in touch with, viewed the protection of historic buildings and scenic beauty as intertwined with the fight for open-air spaces for urban dwellers. They shared the aim to achieve greater moral and physical health for their nations through conservation. Many similarities can also be detected between American and, for instance, German and French attempts to promote an almost ecological consciousness, even if the size of areas available for flora and fauna protection was different.

Tyrrell's analysis demonstrates that the transfer of ideas was not at all unilateral and that the American story is part of a larger global one.

${ }^{3}$ Melanie Hall, "Niagara Falls: Preservation and the Spectacle of Anglo-American Accord", in idem, ed., Towards World Heritage: International Origins of the Preservation Movement, I8701930 (Aldershot: Ashgate, 201 I ), 23-43; idem, "Despoliation or Diplomacy? Britain, Canada, the United States and the Evolution of an English-Speaking Heritage," in Astrid Swenson and Peter Mandler, eds., From Plunder to Preservation: Britain and the Heritage of Empire, I800-1950 (Proceedings of the British Academy, Oxford University Press, forthcoming).

${ }^{4}$ Patrick Kupper, Wildnis schaffen: Eine transnationale Geschichte des Schweizerischen Nationalparks (Bern: Haupt, 20 I 2).

${ }^{5}$ Danny Trom, "Natur und nationale Identität. Der Streit um den Schutz der "Natur" um die Jahrhundertwende in Deutschland und Frankreich," in Etienne François, Hannes Siegrist and Jakob Vogel, eds., Nation und Emotion. Deutschland und Frankreich im Vergleich, Ig. und 20. Jahrhundert (Göttingen: Vandenhoeck \& Ruprecht, 1995), I 47-67; Astrid Swenson, The Rise of Heritage: Preserving the Past in France, Germany and England, 1789-1914 (Cambridge: Cambridge University Press, forthcoming).

${ }^{6}$ Swenson, The Rise of Heritage; and Anna-Katharina Wöbse, Weltnaturschutz: Umweltdiplomatie in Völkerbund und Vereinten Nationen 1920-I95o (Frankfurt am Main: Campus Verlag 2012). 
However, there are also elements in the American experience that remained different from developments elsewhere and these differences can provide thought for further reflection. While the sheer scale of the American wilderness or the active involvement of President Theodore Roosevelt have often been invoked, some more subtle differences and their underlying reasons are probably more interesting to follow up.

Tyrrell points out that, counterintuitively, "American protection of nature after about 1909 came to differ from some European countries in its higher valuation of popular use of the parks, rather than a commitment to preservationist or ecological values." Part of this might be due to the stronger ecological concern of some members of the European conservation movement, such as the influential head of the Prussian State Agency for the Preservation of Monuments of Nature, Hugo Conwentz. Yet it is noteworthy that the question of public access to natural and historic sites excited comparatively little debate in many Continental countries. As most of the land on which historic or natural sites were located belonged to public corporations as a result of the French Revolution and secularization, public access was largely considered a given. On the other hand, the fight for access to historic and natural sites was key to the formation of the preservation movement in Britain. Here, the organized fight for preservation started not so much with historic buildings or sublime landscapes, but with the preservation of commons and footpaths from enclosure by landlords. It would be interesting to see whether the strong emphasis on popular access that Tyrrell observes in America stems more from the peculiarities of the American situation or from the ties between American preservationists and the Commons Preservation Society and the National Trust in Britain.

The rights accorded not just to visitors but also to potential inhabitants of national parks also would benefit from further comparative work. Here a more marked difference existed between Europe and North America. The creation of national parks in North America was from the beginning tied up with debates about the place of Native Americans and the creation of reservations. While the rights of people to live in existing "wildernesses" in Europe was only of real concern in northern Scandinavia, European conservationists, like the architects of the national park in America, were concerned about indigenous peoples in colonies and considered whether national parks there should be inhabited by humans to protect traditional ways of living under European tutelage. An analysis of the flow of debates across the Atlantic and across empires promises to be fruitful not just for the history of national parks but also for the understanding of the nature of preservationist ideas more broadly.7

${ }^{7}$ See Sadiah Qureshi, "Dying Americans: Race, Extinction and Conservation in the New World," in Swenson and Mandler. 
Linked to the debate about the endangerment of indigenous peoples by the advancement of "civilisation," the broader relation between capitalism and conservation offers another fertile area for comparison. Tyrrell's comparison between the controversies over the reservoirs at Hetch Hetchy and Thirlmere shows that Americans and Britons were similarly torn between the preservation of different kinds of resource. Here, like there, beauty was sacrificed to necessity; but here, like there, this also led to a fortification of conservation institutions. The difficult protection of aquatic heritage not only fostered the American national park and the "dawn of green" in Britain, but also led to the creation of nature conservation elsewhere. In France, the fight over the preservation of the source of the Lison gave birth to the French Society for the Protection of Landscape and the first landscape protection laws. In Germany, the failure to save the Laufenburg Rapids from hydropower provided the energy to unite hitherto localized conservation efforts and create the German League for Heimatschutz. In contrast to these similarities, there was, however, a noticeable difference between the largely pro-capitalist stance and millionaire membership of the American Scenic and Historic Preservation Society and the more moderate membership of many European bodies. The middle-class-driven German Heimatschutz movement, in particular, horrified most industrialists with its constant railings, at every national and international occasion, against capitalism's destruction of the environment and of traditional ways of living. ${ }^{8}$

Tyrrell ends his article with reflections on this destructive force, suggesting that "the conservation of resources had been reinterpreted towards tacitly accepting future depletion of American nature's bounty, and of other countries. From that time on, the United States looked increasingly outward, not to a formal empire, but to a growing informal empire of abundance abroad that could sustain the nation's growth." This begs the question whether there is a fundamental link between the emergence of conservation at home and exploitation abroad, not just in America, but in the West. Others have suggested that we need to think more of cultural preservation in relation to the material and human plunder that underpinned the amassing of cultural objects during the slave trade and the age of imperialism. 9 Likewise, the

${ }^{8}$ See, for instance, the reports from the Second International Heimatschutz Congress, Heimatschutz, 8 (1912), 58-59. On membership see William H. Rollins, A Greener Vision of Home: Cultural Politics and Environmental Reform in the German Heimatschutz Movement, 1904-1918 (Ann Arbor: The University of Michigan Press, 1997), p. I04-5.

${ }^{9}$ For instance, during a conference on From Plunder to Preservation: Britain and the Heritage of Empire, King's College, Cambridge, UK, March 2009, Maya Jasanoff (Harvard University) raised the issue of how far we should see the human plunder of empire, in the form of slaves, as analogous to the plunder in the form of artworks. See Astrid Swenson, "The Heritage of Empire," in Swenson and Mandler. 
enduring links between the creation of the conservation institutions in the West and the continuous destruction of natural resources through exploitation and waste dumping in less-affluent countries deserves to be remembered.

Given the scale of global interaction, an interesting question remains, finally, as to why the transnational history of the national park has been remembered as a primarily American one, and why the American side of the story has been reduced to a narrative about American love for wilderness. As Tyrrell shows, the publications by American preservation societies like the American Scenic and Historic Preservation Society were concerned with linking the preservation of the historic, the scenic and the wild, and were teeming with accounts of preservation abroad. Likewise, European publications with a comparative angle analysed conservation in America in a nuanced way. Before the First World War, the annual reports of ASHPS's European sister societies, like the National Trust, or the many parliamentary papers comparing conservation measures across countries in search of imitable solutions, and the growing number of comparative studies like Gerald Baldwin Brown's The Care of Ancient Monuments, published by Cambridge University Press in 1905 and widely read beyond the Anglosphere, all dwelled on the links between historic preservation and nature conservation in America. Often, they even accorded more importance to the historic and scenic measures than to the element of nature conservation. ${ }^{\circ}{ }^{\circ}$ What factors might account for this complex story of exchange - both between various forms of conversation and between countries - being remembered so differently? While this question deserves to be researched in its own right, the mechanisms of remembering and forgetting apparent in other transnational histories might help to shed some light. American historiography, like its European counterparts, became in general more inward-looking in the twentieth century than it had been in the age of nationalism, but this does not suffice as an explanation. Forgetting a transfer could also be more strategic. This is evident, for instance, in the history of history departments. American universities in the process of establishing history departments in the nineteenth century often stressed that they were emulating European, and especially German, models. They acquired credentials by hiring staff with doctorates from abroad. Once departments were firmly established, however, this changed. Keen for $\mathrm{PhD}$ students to remain in the country, the history of transfer was less often mentioned and the

\footnotetext{
${ }^{10}$ Reports from her Majesty's Representatives Abroad as to the Statutory Provision Existing in Foreign Countries for the Preservation of Historical Buildings. Presented to the House of Commons by Command of Her Majesty in pursuance of their Address, 30 July 1897, Parliamentary Papers, (1897), LXXII, p. 367; Gerald Baldwin Brown, The Care of Ancient Monuments. An Account of the Legislative and Other Measures Adopted in European Countries for Protecting Ancient Monuments and Objects and Scenes of Natural Beauty and for Preserving the Aspect of Historical Cities (Cambridge: Cambridge University Press, 1905), pp. 243-48.
} 
Americaness of institutions was stressed. ${ }^{\text {I }}$ Similar processes can be seen in the history of historic-preservation institutions across Europe. Countries in the process of establishing preservation policies frequently referred to foreign policies that should be imitated and proudly acknowledged successful transfers of ideas. Once institutions were securely established, these transfers got fewer mentions. In part this can be explained by the destruction of international networks as a consequence of the First World War; in part it was because the newly established institutions created their own foundation narratives that eclipsed earlier initiatives. As nature and culture preservation were often administered by different agencies, their stories came to be told separately. In contrast, the prewar internationalist meetings, because of their ephemeral nature, had no official memories, and no centralized archives. While there is arguable more continuity in international nature conservation than there is in international historic preservation, the broader aims of nature conservation changed in the interwar years and the increasing emphasis that leading conservationists placed on national parks as wildernesses rather than places of picturesqueness or hunting grounds made invocation of the earlier models perhaps also less desirable.

Yet while all this might help to account for the forgetting of the internationalist and historic side of the national parks' origins, what then about the unchallenged place of America as the inventor of the concept? Why are not the Swedes remembered internationally for their national park system? Why are not the Swiss considered the intellectual proprietors of the national park? In part, the size and growing number of American parks might be responsible. America's rise as a global power provides another reason. Parallel development in historic preservation and the history of museums, where state agents and private players also used similarly broad global networks (which overlapped considerably with those used for the creation of national parks) could suggest that perhaps national prestige and national stereotypes are more important for the dynamics of public quotation and commemoration. During the drafting of preservation legislation or the establishment of museums, material from countries across the globe was used for emulation behind the scenes. In public debates, however, countries were less often cited for the actual advancement of their institutions than for their international reputation. For instance, when French and German preservationists wanted to limit private property rights for the sake of historic preservation they drew with preference on examples from Britain, as the island nation was known for the care she took of the individual's property rights. Moreover, as the greatest empire, Britain

${ }^{11}$ See Gabriele Lingelbach, Klio macht Karriere. Die Institutionalisierung der Geschichtswissenschaft in Frankreich und den USA in der zweiten Hälfte des 19. Jahrhunderts (Göttingen: Vandenhoeck \& Ruprecht, 2003). 
was always worthy of emulation, even if her actual legal provisions were less strong than those of other European and non-European countries. ${ }^{12}$ Comparative accounts on historic preservation increasingly also included the USA as an important international player, even if the United States had fewer historic monuments and less-strong legislation than most of Europe. ${ }^{13}$ It seems likely that champions of national parks followed the same logic. The American model was not simply a good one to reference because of America's primacy in creating the first park in 1872 and due to the size and number of its existing parks; America's rise as a superpower and her new role as a guardian of international order are equally important in this process. During decolonization and in the postcolonial world, the American model might have become even more attractive in order to rid the national park concept of some of its colonial legacies.

A transnational approach to the history of the national parks in America thus tells us much about the international nature of conservation long before the creation of international institutions, and challenges many assumptions about the character of early conservation. Reflecting on why this story has remained unnoticed for so long can also help us better understand how international factors shaped the place of national parks in national consciousnesses across the globe.

${ }^{12}$ See Astrid Swenson, "The Law's Delay? Preservation Legislation in France, Germany and England, I 870-1914," in M. Hall, ed., Towards World Heritage: International Origins of the Preservation Movement, 1870-1930 (Aldershot: Ashgate, $201 \mathrm{I}$ ), I39-54.

${ }^{13}$ E.g. Brown, 243. 